\begin{abstract}
Iranica
Abstracta Iranica Revue bibliographique pour le domaine irano-aryen

Volume 34-35-36 | 2017

Comptes rendus des publications de 2011-2013
\end{abstract}

\title{
Hermann Gasche. Le Südburg de Babylone : une autre visite
}

\section{Rémy Boucharlat}

\section{OpenEdition}

1 Journals

\section{Édition électronique}

URL : http://journals.openedition.org/abstractairanica/41652

DOI : 10.4000/abstractairanica.41652

ISSN : 1961-960X

Éditeur :

CNRS (UMR 7528 Mondes iraniens et indiens), Éditions de l'IFRI

\section{Référence électronique}

Rémy Boucharlat, "Hermann Gasche. Le Südburg de Babylone : une autre visite », Abstracta Iranica [En ligne], Volume 34-35-36 | 2017, document 71, mis en ligne le 15 juillet 2016, consulté le 02 octobre 2020. URL : http://journals.openedition.org/abstractairanica/41652 ; DOI : https://doi.org/10.4000/ abstractairanica.41652

Ce document a été généré automatiquement le 2 octobre 2020.

Tous droits réservés 


\title{
Hermann Gasche. Le Südburg de Babylone : une autre visite
}

\author{
Rémy Boucharlat
}

\section{RÉFÉRENCE}

Hermann Gasche. « Le Südburg de Babylone : une autre visite », in : B. André-Salvini, éd., La Tour de Babylone. Études et recherches sur les monuments de Babylone (Actes du colloque du 19 avril 2008 au musée du Louvre, Paris). Istituto di Studi Civiltà dell'Egeo et del Vicino Oriente et Musée du Louvre, Rome, 2013, p. 115-126

1 Il a été longtemps admis que les rois perses avaient peu construit à Babylone, à l'exception du Perserbau d'Artaxerxès II petit bâtiment hypostyle à un portique. L'A. complète sa démonstration novatrice selon laquelle les palais de Nabuchodonosor II à Babylone ont été fortement remaniés après celui-ci et en particulier par les premiers souverains achéménides (voir sa contribution dans J. Perrot (éd.), Le Palais de Darius à Suse, 2010), le Westhof remanié par Cyrus ou Cambyse, l'Anbauhof à l'ouest par Darius. Cette fois, ce sont les constructions plus à l'est dont l'A. analyse la stratigraphie, les modifications de plans, dont celui des passages, l'emploi et le remploi de briques portant l'estampille du roi babylonien ou bien un lion passant. Une histoire architecturale plus complexe que ne l'a présenté R. Koldewey, le fouilleur de Babylone au début du $\mathrm{XX}^{\mathrm{e}} \mathrm{s}$., qui témoigne des interventions postérieures à Nabuchodonosor, sans doute largement par les premiers rois perses. 


\section{AUTEURS}

RÉMY BOUCHARLAT

CNRS, Lyon 